\title{
¿Cuántas hijas de perra son necesarias para hacer estallar el mundo? Escrituras transgénicas en homenaje a Hija de Perra
}

\author{
Por Lucha Venegas, Cristeva Cabello y Jorge Díaz
}

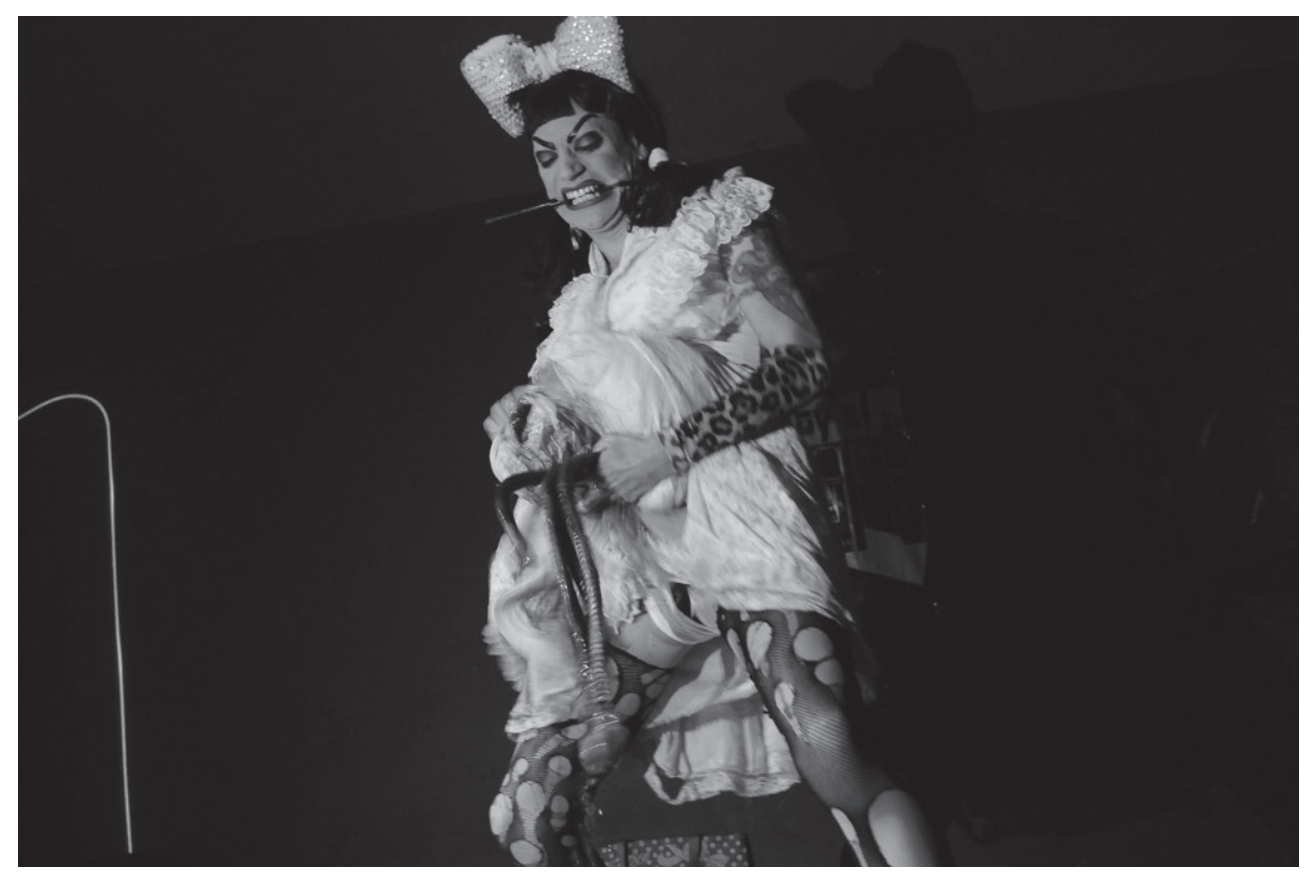

¿Cuántas bombas son necesarias para hacer estallar el mundo? ¿Cuántas hijas de perra somos necesarias para hacerlo estallar? Invitamos a que se tomen la palabra, que se autobiografíen. Hija de Perra insistió en una escritura biográfica donde revisó momentos de infancia en los que narraba cómo había besado a sus compañeros de curso. Fue a partir de esta escritura de investigación sexual que generaba performances donde se develaban las perversiones de la "familia normal". Habitamos las escrituras perras -esas de perra malagradecida-. Nos reverbera Hija de Perra como un reflujo desde nuestras entrañas, como si nos la hubiésemos comido, como si nosotras también fuésemos Hija de Perra. Y es que lo somos. Somos hijas de perra. Mal abortadas, hijas no deseadas, sin origen ni genes claros, quiltras de dudosa procedencia. Somos

Activistas del Colectivo Utópico de Disidencia Sexual (CUDS). 
las problemáticas, las conflictivas, las perras malas y calientes, siempre demasiado incendiarias, siempre demasiado calientes. Un desborde de escasa mesura y aniquilado respeto. Donde todo era inmundicia, donde devolvías la pobreza y el margen a este país que se ve a sí mismo blanco. Tal vez como muchas de ustedes, como la finada Perra, nos nutrimos políticamente las autobiografías con las que nos escribimos una cuerpa que sea una bomba que explote el mundo.

Hija de Perra fue una tremenda e inspiradora compañera en la militancia sexual. Una terrorista sexual que no dejaba género en pie y que al mismo tiempo agrupaba una manada de disidentes culturales. Su partida física deja un gran espacio de orfandad que seguro muchas otras cuerpas continuarán ya sea en el arte, la escritura o la política -o todo eso cruzado y más-. De mujer de pantis rotas a académica de traje de dos piezas, así mutaba Hija de Perra quien nunca tuvo una "identidad verdadera". ¿Qué tan difícil era cargar con ese cuerpo hermonstro, bellestio ${ }^{2}$ y perversamente sexy? En el escenario de una fiesta under donde quizás no había luz o en un auditorio con un público desbordado de universitarixstímidxs que por primera vez escuchaban la palabra heteronorma, así eran los espacios recorridos por Hija de Perra. Como predicadora de una sexualidad indómita y nómada, Hija de Perra nos enseñó que la sexualidad podía incomodar, que podíamos enfrentar al patriarcado y burlarnos del fascismo que está en el saber, la cultura y la política.

Hija de Perra, nos cuesta narrarte en pasado y es que sigues en nuestro presente. No en nuestro futuro, porque al igual que tú, nosotras no tenemos futuro. Una activista con cientos de facetas, que aunque personificara a una dominatrix o una cualquiera, seguía siendo ese perturbador par de cejas, un subrayado a esa mirada amenazante que hacía que su rostro estuviera en un gesto indignante. Una constante mirada crítica. Un rostro crítico y monstruoso que busca"alertar las conciencias sobre lo semivisible"3. Esas cejas rectas de un rostro que no mostraba cansancio frente a una cultura heteropatriarcal, un rostro que respondía con asco a aquellos que se autonombran como normales. Nos demostraste que los enfermos no somos aquellos que la historia nos nombra como anormales, sino aquellos que viven en la opresión de los lazos sanguíneos nacional-capitalistas.

Hija de Perra fue un grito desesperado por romper los límites entre lo que se llama performance y activismo, entre lo que se entiende por pedagogía y por transgresión estética. Su inesperada partida física nos deja un importante patrimonio sexual de la posdictadura y la creación de un anarcobarroco ${ }^{4}$-sexual: discos de música transgénica donde los orgasmos y los anos se convertían en personajes, videoclips como el clásico Reggeaton venéreo donde lo popular-sexual es protagonista, diseños de vestuarios que van desde lo teatral hasta el fetichismo porno, clases de educación sexual donde se

\footnotetext{
2 La Cerda Punk. Ensayos desde un feminismo gordo, lésbiko, antikapitalista y antiespecista, Constanzx Álvarez. Trío Editorial, 2014, Valparaíso.

3 Richard, Nelly. Crítica y Política. Editorial Palinodia, Santiago, 2013, p. 53.

4 Richard, Nelly "Campos de Batalla: una alegoría anarco-barroca” en Revista Papel Máquina. Año 2, № 5, 2010.
} 
mostraban en alta calidad las enfermedades. Performances que trastocaban los límites morales de la izquierda, el feminismo y los partidos GLBT, y además un conjunto de textos que esta pensadora autodidacta y cultivada en el activismo comenzó a escribir al ser invitada a diversas universidades del país por sus alumnos; estudiantes que desde el año 2011 exigen una nueva educación donde las palabras feminismo, pornografía o condiloma no estén prohibidas. Títulos interminables que parodiaban la seriedad de la escritura masculina del saber heterosexual, así era su escritura perra. Textos que "experimentan una política de la lengua como gesto de di/inter/ferir algunos lenguajes más ortodoxos" ${ }^{\prime}$. Uno de sus últimos escritos se publica a modo de homenaje en la Revista Punto Género del Depto. de Sociología de la U. de Chile: "Interpretaciones inmundas de cómo la Teoría queer coloniza nuestro contexto sudaca, pobre, aspiracional y tercermundista, perturbando con nuevas construcciones genéricas a los humanos encantados con la heteronorma".

Hija de Perra siempre se mostró incómoda frente a la categorización queer, ese concepto extranjero que parecía injusto con su cuerpa marginal y con el cual rápidamente la adscribían quienes comenzaron a realizar sus investigaciones sobre género y sexualidad en torno a su figura. Había una desconfianza, una extrañeza, una lejanía frente a este concepto foráneo ¿Acaso se parecían a ella las travestis que se imaginaba Butler al hablar y generar su teoría de la performatividad en un bar de Estados Unidos? En este escrito político de Hija de Perra se hace evidente una crítica a las prácticas colonialistas que impiden ver las particularidades de nuestro sur y que esta artista del margen disloca con preguntas como: "¿Seré una travesti sodomita lésbica ardiente metropolitanizada? ¿Seré una bisexual afeminada en pecado con rasgos contrasexuales y delirio de transgresión a la transexualidad? ¿Seré una tecnomujer anormal con caprichos ninfómanos multisexuales carnales?". Exhibía la enfermedad incurable, esa que se llama transexualidad mental ${ }^{6}$. Aún recuerdo esa historia de amor imposible que nos dejó perplejos en la película Empaná de Pino (2008), donde una Hija de Perra al final del film se enamora de su amiga y sirviente Perdida, un amor translésbico que rechaza el "futurismo reproductivo"7 y que hace evidentes los límites identitarios y del deseo. ¿Dónde queda espacio para el deseo de las viejas calientes, las mujeres con hijos que se emancipan del hogar, los maricas afeminados, las mujeres que se enamoran de travestis? Hija de Perra nos hizo reconocer los límites de una política gay que insiste en ser higiénica, en esconder el sexo, en destinarlo a la reproducción y pedir matrimonio incluso para quienes no tenemos ni siquiera derecho -ni herencias- para poseer una propiedad privada. Así describía la bajada de una noticia el estreno de la película de Wincy Oyarce el año 2008:

"En un local de pollos asados de la calle Santa Rosa se llevó a cabo una de las más inmundas y cachondas fiestas de la marginalidad santiaguina maraca. Por primera vez se exhibió la película que tiene por protagonista a una de las traves mujer más

\footnotetext{
Flores, Valeria. Desmontar la lengua del mandato, criar la lengua del desacato. Editorial Mantis, Santiago, 2014, p. 13 (en imprenta).

6 Presentación Dossier Revista Vozal, № 3. Link: http: //revistavozal.com

7 Edelman, Lee. No al futuro. La teoría queer y la pulsión de muerte. Editorial Egales, Barcelona, 2014, p. 48.
} 
¿Cuántas hijas de perra son necesarias para hacer estallar el mundo? Escrituras transgénicas en homenaje...

promiscua: Hija de Perra. Quien antes de cortarse un pezón en el escenario y hacer unas tijeretas con la Perdida, fue presentada por la distinguida española de pelo rubio La Prohibida. Conozca sobre sexo, caca y transformismo acá" ${ }^{\text {. }}$

Como CUDS -y como otros colectivos artísticos y políticos con los que colaborastemantuvimos un fuerte lazo desde su momento de diva trash, bizarra y underground, recorriendo los espacios más sórdidos y punk del Santiago de la posdictadura con performances donde los excrementos, la sangre y la fiesta nos permitió establecer una suerte de espacio donde existir. Un lugar habitable dentro de la ciudad. Una apropiación de lugares marginales donde era posible conocerla. Nos enseñó y nos acercó el arte de la performance que en ningún museo, liceo o universidad nuestros ojos podrían conocer. Sorprendía la capacidad de preocuparse de cada detalle en sus presentaciones, la calidad de sus acciones en lugares donde no existían los medios básicos para un espectáculo de ese tenor. Las fiestas trans de Hija de Perra fueron ese lugar donde muchos y muchas cobijamos nuestras cuerpas para habitar un rincón de Santiago que no fuera pura violencia, donde el sexo pudiera ser un espacio de risa, donde tuviéramos la posibilidad de gozar con una performance donde esta perra lamía, tragaba y manoseaba con Irina La Loca -la Bigotes- un rosario de madera tamaño $\mathrm{XL}$, el mismo que tenía en su dormitorio nuestra tía, pero ahora vuelto fetiche sexual.

Era el deseo de shock, de anarquía escénica, esa interrupción que asusta, una de las estrategias escénicas de esta artista. Una interrupción a la heteronorma que para algunas podía ser pura violencia, algo inimaginable, aberrante. Pero cuando nos enfrentamos a una política donde un presidente afirma que una niña de 11 años debe y puede ser madre, no se sabe qué pensar, qué es más aberrante, si eso o una trans vestida de novia lamiendo un dildo. Recordamos que alguna vez nos contó que en una fiesta le devolvieron una cabeza de chancho que usaba en sus performances. Ahí estaba el riesgo constante de ser Hija de Perra. En fin, para muchos las fiestas de la Perra fueron una escuela, un lugar donde reconocíamos que la sexualidad no era solo algo romántico, sino donde el devenir perra se convertía en un llamado a la revolución de los cuerpos. En estas fiestas creo que muchos sobrevivimos, nos educamos, aprendimos lo que era una performance, algo que no es más que una investigación permanente. La recordamos vestida de escolar, de obispo, con cachos diabólicos en su cabeza, vestida de mujer de derecha con el cabello rubio. ¿Qué es lo que aprendimos con esta estética travesti? Constanzx Álvarez lo explica muy bien: "Aprendí a dejar de tenerle miedo al ridículo y tratar de ser lo que siempre soñé (...), la performance, la estrella del show, el show pobre que es nuestra vida misma. Exhibición como ejercicio político"9.

Fuiste nuestra heroína trans. Recordamos cómo una vez un decano de Ciencias de la Universidad intentó sabotear tu espectáculo porque en el afiche aparecía una vagina peluda hecha con los materiales de un peluche. Enfrentamos a feministas antipornografía por ti. Tú hacías glamur desde la precariedad, entregabas un discurso fuerte

\footnotetext{
Revista www.cuds.cl, Enero 2008, escrito por Equipo Disidencia Sexual. Ibid, p. 95.
} 
e irreverente desde espacios de fiesta y sexo donde constantemente la censura como una dictadura se hacía presente. Una dictadura sexual que tenemos que continuar haciendo visible las feministas disidentes que te mantenemos en nuestra memoria.

Jamás temiste a la teoría feminista ni de disidencia sexual y fue ahí donde seguimos estableciendo una profunda amistad política y afectiva plasmada en escritos y performances que causaron mucha polémica, como cuando abortaste una cabeza de chancho en el Museo Salvador Allende frente a un cuadro Matta. Con Hija de Perra interrumpimos disidentemente marchas y academias, entramos a museos y desordenamos seminarios. Nuestro mismo recorrido como CUDS está marcado por la presencia de Hija de Perra, no podríamos entender nuestro activismo sin ella y consideramos que esto fue recíproco. La localización de lo queer y nuestra insistencia en una política posidentitaria donde el aborto ocupa un lugar central, enigmático y urgente fue lo que nos mantuvo cercanos y en alianza política.

Hija de Perra, no temiste a hablar de sexo en un país sofocado por el tradicionalismo, la homofobia, el sexismo, el racismo y el miedo a todo lo diferente. Tu discurso no quería pasar desapercibido y ser hablado en voz baja. Utilizaste la estrategia de la exageración como reflejo a un país donde todo es mesura en relación con el sexo. Aplicaste una pedagogía radical en cuanto a la práctica del sexo con tus clases sobre enfermedades venéreas. Tu presencia incomodaba tanto a los conservadurismos de las derechas como de las izquierdas y al mismo tiempo nos motivaste a muchos a aprender que la sexualidad es una creación artística ${ }^{10}$. Con tu estética bizarra sorprendiste los ojos heteronormados de cuantos vieron tu trabajo. Quizás la palabra censura fue una de las que te recorrió como cuerpo desobediente. Tus discursos fueron grabados muchas veces para programas de televisión y jamás se emitieron al aire.

Todas las personas "tienen alma y poto" decía Hija de Perra. Esta era la filosofía trans, esta era la contradicción que comunicaba y ponía en jaque esta artista, educadora, poeta, performer, diseñadora, trabajadora sexual y a veces académica. Todas estas identidades desde una dimensión estratégica, un ejercicio de parodia que realizaba Hija de Perra. La sociedad chilena no era solo ese lugar de lo religioso y espiritual, sino que también era ese lugar del sexo. Su mirada desviada reconocía cómo la sexualidad podía aparecer en todo momento en la televisión, en la familia, en la política. Ya enunciar su nombre obligaba a traer consigo lo peor: Ese nombre maldito y ofensivo que significa ser heredera de una mujer que no alcanzó a ser humana, por suerte diríamos que Hija de Perra no era humana, sino una mutante, un indecencia transgénica.

Hija de Perra fue nuestro primer amor transfeminista, ese de afectos galácticos que hacen de la práctica del sexo un acto radical, esa que pone en el cuerpo la lucha donde todas nuestras ficciones son posibles.

10 Documental de Lucía Egaña (2011). 
¿Cuántas hijas de perra son necesarias para hacer estallar el mundo? Escrituras transgénicas en homenaje...

Hija de Perra fue esa bomba insolente a la institución que norma. Una bomba como Hija de Perra aceleró nuestros corazones disidentes hasta hacerlos explotar. Hija de Perra es el epitafio para nuestros corazones disidentes. Hagamos bombas para la ridícula idea de no volver a verte, Perra. 